\title{
Medical Research Council Manual Muscle Test Score, Abduction
}

National Cancer Institute

\section{Source}

National Cancer Institute. Medical Research Council Manual Muscle Test Score,

Abduction. NCl Thesaurus. Code C139231.

The numerical value that represents the result of a clinical assessment of muscle strength and function during abduction that is based on the Medical Research Council Manual Muscle Test. (Medical Research Council. Aids to examination of the peripheral nervous system. Memorandum no. 45, superseding War Memorandum No. 7. London: Her Majesty's Stationary Office; 1976. doi:10.1016/0022-510X(77)90205-2). 